\title{
ANALISIS PENERAPAN METODE MIND MAPPING MATKUL PSIKOLOGI KOMUNIKASI ISLAM DI INSTITUT UMMUL QURO AL-ISLAMI BOGOR
}

\author{
Suci Sofrada \\ Institut Ummul Quro Al-Islami Bogor, Indonesia \\ Email: suci.sofralda@iuqibogor.ac.id
}

\begin{abstract}
A good learning process is the existence of activeness between educators and students and is supported by adequate learning methods and facilities. Islamic Communication Psychology (PKI) is a social subject (matkul) which has a lot of material that is written or reading material and is a new knowledge that they acquire in the world of education. The mind mapping learning method makes every student interact positively and actively. The position of educators in the mind mapping learning method is as a facilitator and consultant. Educators will only provide stimulation or inducement for discussion material. After that, students are free to develop their learning. In addition, educators also provide limits on the breadth of material for students. This study aims to analyze the process of delivering PKI subject matter material using the mind mapping method, whether it is able to make students more interested and easier to understand the material presented by the lecturers. Data collection through interviews with all students. This type of research is qualitative, in which all students become research subjects. The results of the research analysis show that the use of the mind mapping method increases student interest and creativity in attending lectures on the PKI subject.
\end{abstract}

Keywords: Mind Mapping; Psychology of Islamic Communication; Institute of Ummul Quro AlIslami Bogor

\begin{abstract}
Abstrak
Proses pembelajaran yang baik adalah adanya keaktifan antara pendidik dan peserta didik serta didukung dengan metode dan sarana prasana pembelajaran yang memadai. Psikologi Komunikasi Islam (PKI) merupakan bagian mata kuliah (matkul) sosial yang memiliki banyak bahasan materi yang bersifat tulisan atau bahan bacaan dan merupakan ilmu baru yang mereka peroleh.dalam dunia pendidikan. Metode pembelajaran mind mapping membuat setiap peserta didik berinteraksi secara positif dan aktif. Kedudukan pendidik dalam metode pembelajaran mind mapping adalah sebagai fasilitator dan konsultan. Pendidik hanya akan memberikan rangsangan atau pancingan materi pembahasan. Setelahnya peserta didik bebas mengembangkan pembelajarannya. Selain itu pendidik juga yang memberikan batas keluasan materi bagi peserta didik. Penelitian ini bertujuan menganalisa proses penyampaian materi matkul PKI dengan menggunakan metode mind mapping, apakah mampu membuat mahasiswa lebih tertarik dan mudah memahami materi yang disampaikan dosen pengampu. Pengumpulan data melalui wawancara kepada semua mahasiswa. Jenis penelitian ini adalah kualitatif, dimana semua peserta didik dijadikan subjek penelitian. Hasil analisis penelitian menunjukkan penggunaan metode mind mapping meningkatkan ketertarikan dan kreatifitas mahasiswa dalam mengikuti perkuliahan pada matkul PK.
\end{abstract}

Kata Kunci: Mind Mapping; Psikologi Komunikasi Islam; Institut Ummul Quro Al-Islami Bogor

(C2020 The authors and Komunika. All rights reserved. 


\section{Pendahuluan}

Pendidikan merupakan gerbang pertama bagi manusia untuk memiliki karakter yang berbudi luhur. Pendidikan juga menjadi sarana membuka wawasan manusia akan pengetahuan di dunia serta merupakan kebutuhan dan hak dasar manusia. Apapun latar belakang keluarga, keturunan, dan kemampuan ekonominya. Setiap manusia tidak boleh dilarang untuk mendapatkan pendidikan yang layak dan berkualitas. Sesuai yang tertulis di UU No. 20 tahun 2003 tentang Sistem Pendidikan Nasional (Sisdiknas) Bab 4 pasal 5 menyebutkan bahwa, "Setiap warga negara mempunyai hak yang sama untuk memperoleh pendidikan yang bermutu".

Kemudian dalam UU. No. 20 tahun 2003 tentang Sistem Pendidikan Nasional (Sisdiknas) Bab I pasal 1 menyebutkan bahwa: "Pendidikan adalah usaha sadar dan terencana untuk mewujudkan suasana belajar dan proses pembelajaran agar peserta didik secara aktif mengembangkan potensi dirinya untuk memiliki kekuatan spiritual keagamaan, pengendalian diri, kepribadian, kecerdasan, akhlak mulia, serta keterampilan yang diperlukan dirinya, masyarakat, bangsa dan negara". Proses pembelajaran yang baik adalah adanya keaktifan antara pendidik dan peserta didik serta didukung dengan metode dan sarana prasana pembelajaran yang memadai. Standar proses kurikulum 2013 merubah paradigma guru dalam mengajar yakni dari siswa diberi tahu menuju siswa mencari tahu, dari guru sebagai satu-satunya sumber belajar menjadi belajar berbasis aneka sumber, dari pendekatan tekstual menuju proses sebagai penguatan penggunaan pendekatan ilmiah, dari pembelajaran berbasis konten menuju pembelajaran berbasis kompetensi, dari pembelajaran parsial menuju pembelajaran terpadu, dari pembalaran yang menekankan jawaban tunggal menuju pembelajaran dengan jawaban yang kebenarannya multi dimensi (Mendikbud, 2013).

Psikologi Komunikasi Islam (PKI) merupakan bagian mata kuliah (matkul) sosial yang memiliki banyak bahasan materi yang bersifat tulisan atau bahan bacaan dan merupakan ilmu baru yang mereka peroleh.dalam dunia pendidikan. Hal ini dianggap oleh peserta didik sedikit sulit memahami teori-teori yang berkaitan. Walaupun dalam prakteknya tidak semua perseta didik beranggapan demikian. Sebagai pendidik, penulis tertarik untuk menggunakan berbagai metode pembelajaran agar membuat penyampaian materi kuliah menjadi menarik. Melalui media yang bervariatif, metode-metode yang kreatif dan penyampaian yang menarik. Banyak faktor yang mempengaruhi proses penyampaian materi kuliah, faktor peserta didik yang tidak kooperatif, mengantuk, malas-malasan dalam mengikuti proses pembelajaran. Pendidik yang tidak kreatif dalam mengajar, menggunakan metode ceramah yang membosankan, dan materi yang rumit serta banyak.

Sarana dan prasarana pembelajaran yang minim. Lingkungan keluarga atau teman sejawat dari peserta didik yang kurang bisa mendukung keberhasilan pendidikan serta permasalahan lainnya. Faktor-faktor tersebut membuat semakin peliknya permasalahan dalam penyampaian materi kuliah. Faktor-faktor diatas merupakan permasalahan klasik yang dialami dalam proses pembelajaran yang baik. Bahkan terkadang menjadi membesar dan rumit jika tidak segera dicarikan solusinya. Akan berujung pada tujuan pendidikan nasional yang tidak tercapai. Dalam proses pembelajaran pendidik memegang peran yang penting. Sukses atau 
gagalnya suatu proses pembelajaran dikendalikan oleh pendidik. Oleh sebab itu pemilihan metode menjadi komponen penting saat menyusun rancangan pembelajaran. Salah satu metode pembelajaran yang bisa diterapkan oleh pendidik adalah metode pembelajaran peta kosep/mind mapping. Metode ini memfasilitasi dan merangsang keaktifan peserta didik. Dalam pelaksanaan pembelajaran, peserta didik didorong untuk ikut serta dalam proses pembelajaran dari awal sampai akhir. Sehingga diharapkan akan menciptakan suasana pembelajaran yang menyenangkan dan menarik bagi peserta didik. Sehingga dapat mempermudah peserta didik untuk memahami materi, baik yang mudah maupun rumit sekalipun.

Hal ini merupakan suatu kewajaran, mengingat guru adalah pemegang peranan penting dalam proses pembelajaran di sekolah. Bahkan dinyatakan bahwa guru memberikan kontribusi terbesar (34\%) terhadap prestasi belajar siswa di sekolah (Heyneman \& Locky, dalam Fattah, 2000). Ranah sikap ilmiah sangat menentukan keberhasilan seorang peserta didik untuk mencapai ketuntasan dalam proses pembelajaran (Hunaepi, 2016). Metode pembelajaran peta konsep/mind mapping membuat setiap peserta didik berinteraksi secara positif dan aktif. Demi menyelesaikan materi yang dihadirkan dalam proses pembelajaran. Kedudukan pendidik dalam metode pembelajaran peta konsep/mind mapping adalah sebagai fasilitator dan konsultan. Pendidik hanya akan memberikan rangsangan atau pancingan materi pembahasan. Setelahnya peserta didik bebas mengembangkan pembelajarannya. Selain itu pendidik juga yang memberikan batas keluasan materi bagi peserta didik. Serta menjadi konsultan penyelesaian masalah jika peserta didik mengalami kendala.

Hal di atas bisa menjadi harapan bagi metode pembelajaran peta konsep/mind mapping. Dapat meningkatkan hasil belajar bagi peserta didik. Peserta didik dalam proses pembelajarannya tidak bosan dan dapat menangkap materi dengan baik. Dari penjabaran di atas peneliti tergerak untuk melakukan penelitian yang berjudul: "Analisis Penerapan Metode Pembelajaran Mind Mapping pada Matkul Psikologi Komunikasi Islam di Institut Ummul Quro Al-Islami Bogor”.

\section{Metode}

Penelitian dilaksanakan dalam bentuk penelitian lapangan, pengambilan data langsung dari objek penelitian. Metodologi penelitian ini menggunakan teknik penelitian kualitatif. Metode ini sendiri sering diberlakukan pada ilmu-ilmu kebudayaan yang mencakup humaniora, sejarah, dan ilmu sosial yang bertujuan untuk menemukan gejala yang unik atau induvidual dan bukan mencari hukumhukum umum seperti pada ilmu-ilmu alam (Priyadi, 2012). Selain itu metode penelitian kualitatif atau naturalistic inquiry merupakan prosedur penelitian yang menghasilkan data deskriptif berupa kata-kata tertulis dan lisan dari orang-orang dan perilaku yang dapat diamati (Suharsaputra, 2018). Kemudian, 2) Metode kuantitatif dinamakan metode tradisional, metode ini disebut metode kuantitatif karena data penelitian berupa angka-angka dan analisis menggunakan statistik (Ashari, 2016).

Dalam penelitian ini peneliti ingin mengangkat sisi sosial yang tidak bisa ditafsirkan seluruhnya dengan angka. Namun harus melalui penggalian sumbersumber (wawancara), pendapat koresponden dan observasi secara langsung di lapangan. Selama masa pengumpulan data peneliti akan memilih koresponden 
yang sesuai dengan tujuan penelitian. Agar tersedia data yang sesuai dengan yang diharapkan.

Dalam penelitian terdapat beberapa tahap penelitian, yaitu: (1) tahap perencanaan, pada tahap ini peneliti akan menyusun dasar penelitian, rancangan penelitian, objek penelitian serta metode penelitian, (2) tahap pelaksanaan, pada tahap ini peneliti akan melakukan penerapan metode pembelajaran mind mapping kepada objek penelitian dan mengumpulkan data penelitian, (3) tahap analisis data, pada tahap ini peneliti akan melakukan analisis data yang telah didapat selama tahap pelaksanaan menggunakan teknik analisis data yang telah ditentukan sebelumnya, (4) tahap evaluasi, pada tahap ini peneliti akan mengadakan penafsiran atas hasil analisis data setelah penerapan metode peta konep/mind mapping pada penyampaian materi PKI yang telah dilakukan sebelumnya.

\section{Hasil dan Pembahasan}

Dalam penelitian ini, jumlah subjek penelitian keseluruhan adalah 9 orang mahasiswa Prodi Komunikasi Penyiaran Islam (KPI) semester 5 di kampus Institut Ummul Quro Al-Islami (IUQI) Bogor. Mengingat jumlah subjek yang sedikit, maka peneliti mengambil semua sebagai subjek penelitian dan hanya menggunakan tehnik wawancara.

\section{a. Analisis Data Wawancara}

Hasil analisis peneliti terhadap pertanyaan-pertanyaan yang peneliti ajukan kepada informan merujuk pada pedoman kisi-kisi wawancara, adalah sebaagai berikut:

Pertanyaan 1: Bagaimana pendapat kamu tentang matkul Psiokologi Komunikasi Islam (PKI)? “. Hasil analisis: 'Sebagian besar informan (mahasiswa) menjelaskan bahwa mereka menyukai matkul PKI. Karena kita dapat memahami ekspresi wajah lawan bicara kita ketika berkomunikasi. Selain itu, matkul PKI tidak membosankan atau menjenuhkan dan juga melalui matkul PKI dapat mempelajari banyak hal mengenai psikologi dalam berkomunikasi “. Pertanyaan 2: "Jelaskan adakah hal yang membuat kamu kesulitan/kendala ketika memahami materi matkul PKI! “. Hasil analisis: "Dari penjabaran informan (mahasiswa) kebanyakan kesulitan yang dialami adalah ketika menemukan istilah yang baru didengar yang membutuh konsentrasi ketika mengikuti kuliah, dan banyak teori yang belum diketahui karena belum pernah mendengar serta dipraktekkan juga dikarenakan belum senang dengan matakuliah ini. "Pertanyaan 3: "Sebutkan dan jelaskan cara belajar apa saja yang sering digunakan pendidik dalam penyampaian matkul PKI? ". Hasil analisis: "Ketika proses pembelajaran dosen memberikan materi secara langsung, menggunakan media laptop atau pun papan tulis kemudian peta konsep/mind mapping akan didiskusikan bersama “.

Pertanyaan 4: "Apakah dalam penyampaian materi PKI pernah menggunakan metode peta konsep/mind mapping? "Hasil analisis: "Menurut semua informan (mahasiswa), dosen pengampu mata kuliah PKI sudah pernah menerapkan metode peta konsep/mind mapping dalam proses penyampaian materi matkul PKI “. Pertanyaan 5: "Jelaskan bagaimana proses pembelajaran menggunakan metode mind mapping? ". Hasil analisis: "Menurut informan (mahasiswa) proses pembelajaran dengan metode mind mapping ini cukup mudah karena memudahkan 
mahasiswa memahami serta dapat mengasah kreatifitas mahasiswa yang menerapkannya. Dosen menjelaskan memakai media whiteboard ataupun memakai media Powerpoint terlebih dahulu teori-teorinya, kemudian diapplikasikan ke dalam bentuk peta konsep agar mudah dipahami dan mudah dingat. Hal tersebut membuat proses pembelajaran menjadi menarik sehingga tidak membosankan".

Pertanyaan 6: "Bagaimana pendapatmu setelah penyampaian materi matkul PKI menggunakan metode mind mapping? "Hasil analisis: "Setelah informan (mahasiswa) mengalami proses pembelajaran menggunakan metode peta konsep/mindmapping. Informan (mahasiswa) merasa lebih mudah memahami materi yang disampaikan dosen. Selain itu, Proses belajar yang menarik dan tidak membosankan".

Pertanyaan 7: "Apakah kamu merasa kesulitan dengan penyampaian materi matkul PKI jika menggunakan metode mind mapping? "Hasil analisis: "Tidak ada kesulitan dalam prses pembelajaran yang dirasakan oleh informan (mahasiswa), dan informan (mahasiswa) merasakan keseruan dan ketertarikan dalam proses pembelajaran menggunakan metode peta konsep/ mind mapping. Pertanyaan 8: "Apakah menurut kamu dengan menggunakan metode mind mapping, dapat meningkatkan kreativitas mahasiswa? Berikan alasannya. Hasil analisis: "Informan (mahasiswa) menjelaskan bahwa melalui penggunaan mind mapping dengan merangkai sendiri konsep suatu teori yang dapat dengan mudah dingat oleh diri sendiri maupun orang lain. Selain itu, menggunakan mind mapping mahasiswa merasa lebih seru dan menarik, membuat proses pembelajaran lebih efektif dan seru karena mind mapping merupakan konsep yang berbeda. Dan dengan metode mind mapping dapat meningkatkan kreatifitas mahasiswa karena dapat membuat point-point dalam pembelajaran semenarik mungkin guna mudah memahami materi”.

Pertanyaan 9: "Apakah menurut kamu dengan menggunakan metode mind mapping, dapat membuat kamu lebih mudah paham materi matkul PKI? Berikan alasannya. Hasil analisis: "Penerapan metode peta konsep/mind mapping mampu membuat kata-kata yang singkat dan efektif yang dapat dihafalkan dengan mudah tidak terlalu banyak hanya cukup kata-kata kunci saja, yang kemudian dapat kita kembangkan sendiri sesuai dengan definisi atau teori yang berhubungan".

\section{Kesimpulan}

Berdasarkan hasil penelitian yang dilakukan di lingkungan kampus Institut Ummul Quro Al-Islami (IUQI) Bogor tentang penerapan metode mind mapping pada mata kuliah Psikologi Komunikasi Islam (PKI), maka peneliti menyimpulkan penerapan mind mapping adalah: Sebagian besar informan (mahasiswa) menjelaskan bahwa mereka menyukai matkul PKI. Karena kita dapat memahami ekspresi wajah lawan bicara kita ketika berkomunikasi. Selain itu, matkul PKI tidak membosankan atau menjenuhkan dan juga melalui matkul PKI dapat mempelajari banyak hal mengenai psikologi dalam berkomunikasi. Kebanyakan kesulitan yang dialami adalah ketika menemukan istilah yang baru didengar yang membutuh konsentrasi ketika mengikuti kuliah, dan banyak teori yang belum diketahui karena belum pernah mendengar serta dipraktekkan juga dikarenakan belum senang dengan matakuliah ini. 
Kemudian semua informan mengakui dosen pengampu mata kuliah PKI sudah pernah menerapkan metode peta konsep/mindmapping dalam proses penyampaian materi matkul PKI dan menurut mereka proses pembelajaran dengan metode mind mapping ini cukup mudah karena memudahkan mahasiswa memahami serta dapat mengasah kreatifitas mahasiswa yang menerapkannya. Dosen menjelaskan memakai media whiteboard ataupun memakai media Powerpoint terlebih dahulu teori-teorinya, kemudian diapplikasikan ke dalam bentuk peta konsep agar mudah dipahami dan mudah dingat. Hal tersebut membuat proses pembelajaran menjadi menarik sehingga tidak membosankan.

Setelah informan (mahasiswa) mengalami proses pembelajaran menggunakan metode peta konsep/mindmapping. Informan (mahasiswa) merasa lebih mudah memahami materi yang disampaikan dosen. Selain itu, Proses belajar yang menarik dan tidak membosankan. Mereka merasakan keseruan dan ketertarikan dalam proses pembelajaran menggunakan metode peta konsep/mind mapping. Penggunaan metode mind mapping dengan merangkai sendiri konsep suatu teori yang dapat dengan mudah dingat oleh diri sendiri maupun orang lain. Selain itu, menggunakan mind mapping mahasiswa merasa lebih seru dan menarik, membuat proses pembelajaran lebih efektif dan seru karena mind mapping merupakan konsep yang berbeda. Dan dengan metode mind mapping dapat meningkatkan kreatifitas mahasiswa karena dapat membuat point-point dalam pembelajaran semenarik mungkin guna mudah memahami materi.

Penerapan metode peta konsep/mind mapping mampu membuat kata-kata yang singkat dan efektif yang dapat dihafalkan dengan mudah tidak terlalu banyak hanya cukup kata-kata kunci saja, yang kemudian dapat kita kembangkan sendiri sesuai dengan definisi atau teori yang berhubungan. Berdasarkan kesimpulan dari hasil menganalisis, maka peneliti menyarankan kepada para pendidik dari berbagai tingkat pendidikan agar proses penyampaian materi belajar berhasil dengan baik sesuai tujuan pendidikan tersebut maka: Pendidik sebaiknya mengunakan berbagai macam metode penyampaian materi kepada peserta didik khususnya matkul bidang sosial. Pendidik dapat mengunakan metode mind mapping adalah salah satu metode yang dapat digunakan untuk menarik peserta didik agar lebih tertarik mengikuti proses belajar dan lebih kreatif.

\section{Daftar Pustaka}

Ashari, L. H. (2016). Instrumen penilaian unjuk kerja siswa SMP kelas VIII dengan model peer asssessment berbasis android pada pembelajaran penjasorkes dalam permainan bola voli. Journal of Educational Research and Evaluation, 5(11).

Fattah, Nanang. (2000). Manajemen berbasis sekolah, strategi pemberdayaan sekolah dalam rangka peningkatan mutu dan kemandirian sekolah. C.V. Andira.

Hunaepi. (2016). Kajian literatur tentang pentingnya sikap ilmiah. Prosiding dalam Seminar Nasional Pusat Kajian Pendidikan Sains dan Matematika.

Kemendikbud. (2014). Konsep dan implementasi kurikulum 2013. Kemendikbud.

Priyadi, S. (2012). Metode penelitian pendidikan sejarah. Penerbit Ombak.

Suharsaputra, U. (2018). Metode penelitian (kuantitatif, kualitatif dan tindakan). P.T. Refika Aditama.

UU No. 20 tahun 2003 tentang Sistem Pendidikan Nasional (Sisdiknas). 